\title{
Diversity of Dragonfly Genus Drepanosticta in Tourism Forest Curug Cipendok, Banyumas District
}

\author{
Mokhamad Nur Zaman ${ }^{1 *}$, Bakhtiar Fahmi Fuadi ${ }^{1}$, Akhmad Sultoni ${ }^{2}$ \\ ${ }^{1}$ Biology Department, Faculty of Science and Technology UIN Sunan Kalijaga \\ J1. Marsda Adisucipto No. 1 Yogyakarta 55281, Indonesia. Tel. + 62-274-540971, Fax. + 62-274-519739 \\ ${ }^{2}$ Mathematic Department, Faculty of Mathematic and Natural Science, Gadjah Mada University \\ Bulaksumur, Caturtunggal, Yogyakarta 55281, Indonesia. Tel. +62 (274) 6492599, Fax. +62 (274) 565223 \\ "Email: azamavicenna@gmail.com
}

\begin{abstract}
Cipendok especially have rich biodiversity. One of the themes is Javanese endemic dragonfly. Around 3 Javanese endemic dragonfly species was recorded in Curug Cipendok. Collection data was carried out in July until August 2017. The method used was exploration following path in several habitats, namely plantation, secondary forest, Pocung lake and field. Purpose of this study is to record the diversity of Javanese endemic dragonfly and distribution Drepanosticta in forest tourism curug Cipendok. The result from this observation is found three species that is Drepanosticta sundana, Drepanosticta gazella, and Drepanosticta spatulifera. The highest population is Drepanosticta gazella with $48 \%$ from totally individual and lowest is Drepanosticta sundana 13\%. The diversity with Shannon-Wiener index is 0.97 that is low diversity. From observation distribution of Drepanostica only founded in a specific habitat, that is a secondary forest.
\end{abstract}

Keywords: Banyumas, Cipendok, Dragonfly, Endemic, Java

\section{INTRODUCTION}

Drepanosticta is Javanese endemic species, and they are very sensitive with disturbance that required natural habitat in nature. However, the rate of deforestation in Indonesia has a negative impact on animals there, as well as Dragonfly. All of the species on ordo Odonata have a dependency on water availability. Because when laying eggs, must be placed deep in the water (Subramanian, 2005).

Drepanosticta needs natural habitat with high quality, not all habitat can support it. They have limited distribution, can be found only in a special place (Orr, 2003). The main threat for its survival is the loss of natural habitat in Java forest. Whereas the data about Drepanosticta are very slight. Research and survey are needed to solve the problem and as an initial step to conservation (Dow, 2009).

The example research that has been done, like Diniarsih (2016) do research about study microhabitat and population Javanese endemic species Drepanosticta in Ungaran mountain slope mountain. Rachman dan Rohman (2016) find index diversity dragonfly in Menoreh karst Central Java and Special Region Yogyakarta wherein the research find three Drepanosticta, that is D. sundana, D. gazella, and D. Spatulifera. While researching in the Slamet slope mountain about Drepanosticta, no research until 2016.

Data collection of dragonfly in Curug Cipendok is needed to be done, as discovery Drepanosticta in this region last time was done in the year 1954 (Lieftinck, 1954). Conversion forest becomes a tourist place in there raises problems of regional damage caused by the entry of human activity. Budiman (2013) record visitors Curug Cipendok at 2009-2013 average is 51.645. The potential for garbage as a source of environmental pollution.

Therefore study the diversity of dragonfly genus Drepanosticta in Forest Tourism Curug Cipendok is necessary. This research exploration following path in several habitats, namely plantation, secondary forest, Pocung lake and field. Purpose of this study is to record the Diversity of Javanese endemic dragonfly and distribution Drepanosticta in tourism forest Curug Cipendok. Results from this research can be used as consideration management of environmentally friendly tourist areas and friendly to biodiversity habitat. So sustainability of Javanese endemic species and other diversity can be maintained.

\section{MATERIALS AND METHODS}

\section{Study Area}

This research conducted in Wanawisata Curug Cipendok, sub-district Cilongok, Banyumas District with four ecosystems provided there, that is plantations, secondary forest, lake Pocung, and the field.

\section{Procedures}

\section{Data Retrieval of Dragonflies}

Data collection was done at 09:30 am until $01.00 \mathrm{pm}$, as the dragonfly (include insects) that are active in the day. Every ecosystem divided into a shaped plot with a size $10 \times 10$ meters, according to the area ecosystem 
that can be observed. Then choose the plot to be taken the data with random sampling, $10 \%$ of the total plot respectively ecosystem. Dragonflies are found recorded name type, amount individual, and marked location with GPS.

\section{Data Analysis}

Identification of species was using book identification of the Dragonfly of Yogyakarta (Setiyono et al., 2017). The number of individuals that are analyzed using Shannon-Wiener diversity index that criteria of species diversity indicates, if $\mathrm{H}^{\prime}>3$ means the species in diversity is high. If the value $H^{\prime} 1 \leq H^{\prime} \leq 3$ means the level of diversity is medium, whereas if $H^{\prime}<1$ means the level of diversity is low. Shannon-Weiner diversity index is calculated according to Odum (1998):

$$
\mathrm{H}^{\prime} \quad=-\frac{n i}{N} \sum \log \frac{n i}{N}
$$

Information:

$$
\begin{array}{ll}
\mathrm{H}^{\prime} & =\text { Shannon-Weiner diversity index } \\
\mathrm{ni} & =\text { Number of individuals in some species } \\
\mathrm{N} & \quad=\text { Total number of individual in all species }
\end{array}
$$

\section{RESULTS AND DISCUSSION}

Dragonfly member of the Drepanosticta genus in Tourism Forest Curug Cipendok are 3 species of 5 species in Java. According to Lieftinck (1954) Javanese endemic species is $D$. sundana, D. gazella, D. spatulifera, D. bartelsi, and D. sibersi. Whereas in Curug Cipendok only found D. sundana, D. gazella, D. spatulifera (Table 1). As research Herlambang (2016) in the Tourism Area Curug Lawe Benowo Kalisidi West Ungaran found 3 types Drepanosticta only.

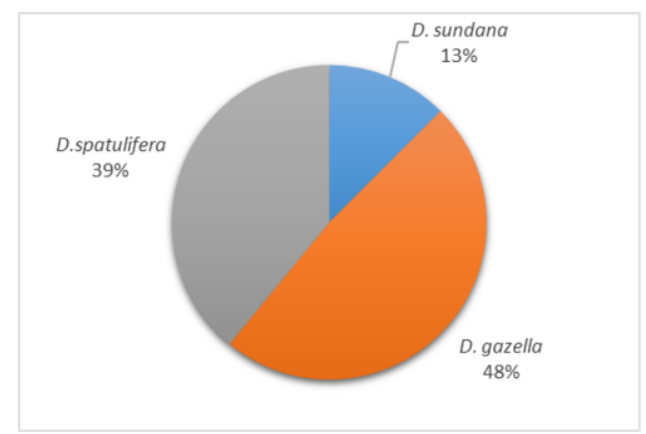

Figure 1. Percentage of three species Javanese endemic dragonfly in Curug Cipendok.

The total number of the whole species is 64, consisting of $31 \mathrm{D}$. gazella species, $25 \mathrm{D}$. spatulifera species, and $8 \mathrm{D}$. sundana. The most frequent types found for research is D. gazella. Discoveries are

\begin{tabular}{|c|c|}
\hline Species & Description \\
\hline Drepanosticta sundana & $\begin{array}{l}\text { Compound eyes are black on the top and greenish white at the bottom. Male D. sundana has an } \\
\text { abdomen with a bluish-white spot that is wide enough on the } 8^{\text {th }} \text { section of the upper surface or } \\
\text { tingle, while females have } 2 \text { small spots on the } 9^{\text {th }} \text { and } 10^{\text {th }} \text { segments. Each segment in the } \\
\text { abdomen has white patches that form striped. The female abdominal end will be larger than } \\
\text { previous. This section is used as secondary genitalia for copulation. His body size is longer than } \\
\text { the other two Drepanosticta species. In } D \text {. sundana piston there are colored ribbons white ivory } \\
\text { number } 2 \text {. Different } D \text {. Gazella only has line The sum to } 1 \text {. Ribbons form line parallel to the } \\
\text { anterior part. One of them key identification species this is part } 2 \text { line parallel to the piston. }\end{array}$ \\
\hline Drepanosticta gazella & $\begin{array}{l}\text { The lower mandible, klipeus and labrum are ivory white, surrounded by black. Black eyes. The } \\
\text { anterior lobe has black spots in the middle. In the piston there is a pale white line, one of the } \\
\text { identification characteristics that distinguish it from other species is in this part of the line. } \\
\text { Male } D \text {. gazella has a posterior part with specialized prothorax forming black lobes. Long and } \\
\text { pointed with curved ends (Lieftinck, 1929). The lobes found in males are greater than those of } \\
\text { females. The thoracic section has an ivory white line and is a distinctive marker to distinguish } \\
\text { from other species. The compound eyes on this dragonfly are all black. } \\
\text { The male abdomen has } 2 \text { small blue patches that are parallel to section } 9 \text {. The females have more } \\
\text { light blue strokes than the female } D \text {. spatulifera. The female abdominal end is more bulging as a } \\
\text { place of copulation, this part is the secondary genitals. }\end{array}$ \\
\hline Drepanosticta spatulifera & $\begin{array}{l}\text { Has special characteristics, namely in the anterior thoracic section is black and there is no white } \\
\text { line. One identification that can be clearly seen is this part, because the other members of the } \\
\text { Drepanosticta genus are endemic to other Javanese, having white lines on the lateral side of the } \\
\text { thorax. Abdomen colored black and white. The tip of the ventral abdomen, there style blue in } 2 \\
\text { segments it ends. Where in males spotting blue wide found in section } 8-10 \text {. Often seen curved } \\
\text { at the tip of the abdomen. This is one of the tip of the abdomen identification striking for } \\
\text { distinguishing with Drepanosticta another. In females spotting blue at the end of the abdomen } \\
\text { only a little only named in section } 9 \text {. }\end{array}$ \\
\hline
\end{tabular}
reached $48 \%$ of total species. While D. sundana is kind of the least found when data retrieval.

Table 1. Description of three species of drepanosticta in Curug Cipendok. 
The results of dragonfly diversity analysis using the Shannon-Weiner diversity index show Drepanosticta sundana has 0.25 diversity index. Drepanosticta gazella has 0.35 diversity index. Drepanosticta spatulifera has 0.37 diversity index. The higher index is Drepanosticta spatulifera. The smallest diversity index Drepanosticta sundana. Dragonfly diversity index charts can be seen in the Table 2 Dragonfly diversity index of Curug Cipendok is only 0.97, so it can be concluded that the diversity of dragonflies is low.

Table 2. Diversity index of three species of Drepanosticta in Curug Cipendok.

\begin{tabular}{lll}
\hline Species & Total of Individu & $\mathbf{H}^{\mathbf{}^{\prime}}$ \\
\hline D. sundana & 8 & 0.25 \\
D. gazella & 31 & 0.35 \\
D.spatulifera & 25 & 0.37 \\
Total & 64 & 0.97 \\
\hline
\end{tabular}

Research showing that Drepanosticta only found in the secondary forest whereas in three ecosystems others are not. Dragonfly member family Platystictidae is one of its members with genus Drepanosticta including animal stenotopic, as life in forest habitat specifically (Van Tol, 2009). Condition Forest secondary when this have river with still water clear so that Drepanosticta choose as the place his life. Lieftinck (1954) mentions Drepanosticta putting the egg in the clear water when mate season and grow in the location. Because eggs, nymphs, until the time of the Drepanosticta imago very sensitive to pollution environment, especially in waters. According to Indonesian Dragonfly Society (2011), the member of Drepanosticta genus is a species that very limited spread and need special habitat requirements.

Drepanosticta only found in a certain place. Data retrieval results show selected location for activity which closes with a source of water. The water flow is not too profusely with cover dense canopy. As results research Diniarsih (2016) D. spatulifera is $73 \%$ found in rivers, $18 \%$ in seepage, and $9 \%$ other found in the border. While $D$. sundana $79 \%$ found in rivers, $7 \%$ in seepage, and $14 \%$ in border. D. gazella $36 \%$ found in the river, $9 \%$ at the border, and $55 \%$ other found in the area seepage. According to Mc Peek (2008), some a limiting factor existence and distribution dragonfly in something habitat is habitat type, availability feed, and interactions related with dragonfly life-cycle. All factor that each other related and influence one same other.

The highest percentage type is D. gazella at $48 \%$. Ecosystem Forest secondary is a suitable habitat for type $D$. gazella, with circumstances dark dissertation dense vegetation. Addition to conformity habitat and have source power in the form of food, difference ability every type for competing in a habitat can influence abundance individual and dominance something type. According to Johansson et al. (2008) each type dragonfly have morphology defense body
Different, distinctions this take effect to interaction inter type.

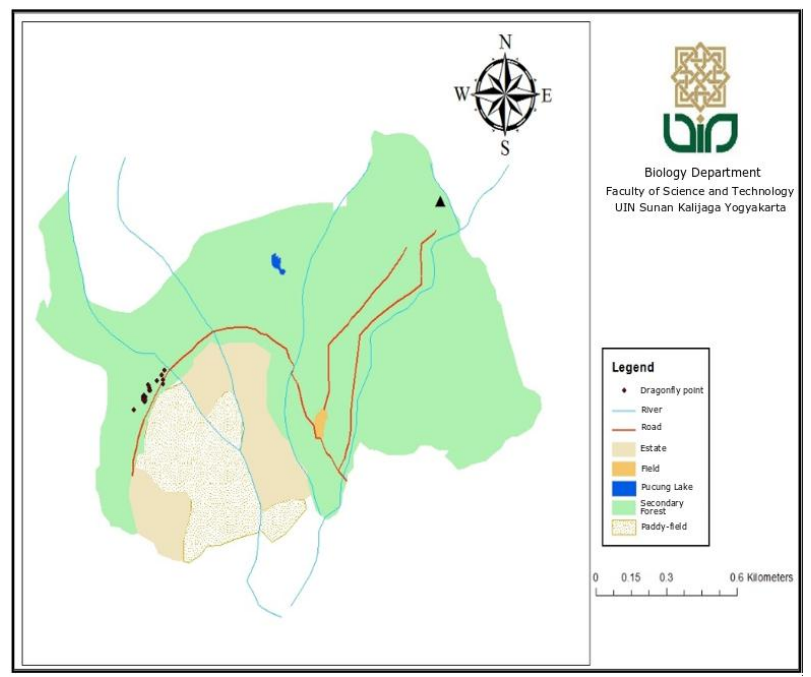

Figure 2. Distribution of three species Javanese endemic Dragonfly Drepanosticta in Curug Cipendok.

Data retrieved in three another ecosystem, no found Drepanosticta. One of them ecosystem is area rice fields around ecotourism curug Cipendok. As results research Ansori (2009) who did study diversity Odonata planted around Bandung, West Java, no find type from genus Drepanosticta there.

\section{Discussion}

Research this give get biodiversity in wanawisata waterfall Cipendok. There are 3 types member of the Genus Drepanosticta, ie D. sundana, D. gazella, D. spatulifera of 5 species recorded in Java. One of them the part whose value very important for data collection diversity biological Indonesia. Research results showing total individual below 50, with index less diversity from 1. Meaning potential experience extinction in the region curug Cipendok. Clean habitat from intervention activity human as disposal garbage carelessly, being a very factor influence rate decrease total Drepanosticta. Then from that need do arrangement back region tourism, and regulation to visitors to look after sustainability environment region.

\section{CONCLUSIONS}

From the result it can be concluded that the dragonfly member of the Drepanosticta genus in Tourism Forest Curug Cipendok only found 3 species of 5 species in Java, that is Drepanosticta sundana, Drepanosticta gazella, and Drepanosticta Spatulifera. The total number of the whole species is 64 , consisting of $31 \mathrm{D}$. gazella species, $25 \mathrm{D}$. spatulifera species, and $8 \mathrm{D}$. sundana. The most frequent types found for research is D. gazella. Discoveries are reached $48 \%$ of total 
species. While D. sundana is kind of the least found when data retrieval.

The analysis using the Shannon-Weiner diversity index showed that Drepanosticta sundana has 0.25 diversity index (the smallest index). Drepanosticta gazella has 0.35 diversity index. Drepanosticta spatulifera has 0.37 diversity index. The higher index is Drepanosticta spatulifera.

Dragonfly diversity index of Curug Cipendok is only 0.97 , so it can be concluded that the diversity of dragonflies is low. Research showing that Drepanosticta only found in the secondary forest whereas in three ecosystems others are not.

\section{ACKNOWLEDGMENTS}

We would like to say thanks to Eka Sulistyowati and Siti Aisah as our lecturer. Thanks to Joko Setiyono and Siti Diniarsih from Capung Indonesia that help in identification, and thanks to Fathurahman Sidiq from Green Community UNNES, Sungkono from Matala Biogama, Sigit Yudi N, Rizky Chandra SI, Laila, Apriatun Nafisah, Maat Z, Febrian, and Zainul L from BIOLASKA UIN SUKA, Aya from UNSOED Biology, and Arfiansyah Adi from Biologisatu.

\section{REFERENCES}

Ansori, I. 2009. Keanekaragaman Nimfa Odonata (Dragonflies) di beberapa persawahan sekitar Bandung Jawa Barat. (Skripsi). Fakultas Keguruan dan Ilmu Pendidikan UNIB.
Budiman, M. A. K. 2014. Potensi pengembangan wisata birdwatching di wanawisata curug Cipendok Banyumas Jawa Tengah. [Skripsi]: IPB

Diniarsih, S. 2016. Studi Mikrohabitat dan Populasi Capung Endemik Jawa Anggota Genus Drepanosticta (Odonata: Platystictidae) di Gunung Ungaran, Jawa Tengah. [Tesis]. Universitas Gadjah Mada Yogyakarta

Dow, R.A. 2009. Drepanosticta sundana. The IUCN Red List of Threatened Species. Version 2014.2. <www.iucnredlist.org>. Downloaded on 06 August 2014.

E.P. Odum .1999. Dasar - dasar ekologi, Yogyakarta: UGM press.ch.3, pp. 178-180

Herlambang A.E.N, Mochamad H, Udi T .2016.Struktur Komunitas Capung di Kawasan Wisata Curug Lawe Benowo Ungaran Barat. Bioma. 18 (1) : 70-78

Johansson, F, Mikolajewski, D.J. 2008. Evolution of Morphological Defences. Aguilar, A.C. (eds). Dragonflies and Damselflies: Model Organisms for Ecological and Evolutionary Research. Oxford University Press Inc. New York

McPeek, M. A. 2008. Ecological Factors Limiting The Distributions and Abundances of Odonata. Aguilar, A.C. (eds). Dragonflies and Damselflies: Model Organisms for Ecological and Evolutionary Research. Oxford University Press Inc. New York.

Orr, O.G. (2003) A Guide To The Dragonfly of Borneo. Natural History Publication (Borneo).

Rachman H.T., and Rohman, A. 2016. Dragonfly Diversity (Odonata) in Menoreh Karst Central Java-Yogyakarta. Int'1 Journal of Advances in Agricultural \& Environmental Engg. (IJAAEE). Vol.3: 255-258.

Subramanian, K.A.2005. Dragonflies and Demselflies of Peninsular India-A Field Guide. A collaboration of centre for Ecological Science, Institute of Science, Bangalor and Indian Academy of Science

Van Tol, J. (2009). Phylogeny and Biogeography of the Platystictidae (Odonata). P.hD Thesis: Leiden University 